\title{
Harmonisasi Asuransi Syariah dalam Maqashid Syariah dan Perundangan di Indonesia
}

\author{
Muhammad Ilham \\ ${ }^{1}$ Program Studi Hukum Ekonomi Syariah, STAIN Sultan Abdurrabman Kepulauan Riau \\ e-mail: ilham@stainkepri.ac.id
}

\begin{abstract}
ABSTRAK. Kajian tentang Asuransi Syariah telah dikaji dalam fatwa DSN-MUI Nomor 21/DSN-MUI/X/2001, yaitu Asuransi Syariah. Meskipun demikian bahwa perlu kembali untuk mengkaji dalam konsep Maqashid Syariah dan Peraturann Undang-undang di Indonesia. Mengacu pada kajiannya bahwa pendekatan yang diterapkan dalam tulisan ini beupa kajian kualitatif dengan sumber berupa fatwa DSN-MUI dan Peraturan yang terkait dnegan perasuransian secara umum. Dalam kesimpulan yang didapatkan bahwa pada dasarnya implementasi teori maqasid asy-syariah memberi warna baru dalam pembahasan asuransi. Ada titik temu antara tujuan ditetapkannya syariah dengan maksud diadakannya asuransi. Peranan asuransi dalam melindungi al-kulliyah alkhams bisa berupa ijabiyah (perwujudan), bisa juga berupa salbiyah (pencegahan/penolakan). Sehingga secara filosofis bahwa maksud dan tujuan seorang muslim dalam mengikuti program asuransi dengan niatan melindungi agama, jiwa, akal, keturunan, harta dan kehormatan. Secara esensial dapat dikatakan bahwa adanya prinsip-prinsip hukum asuransi, tidak bertentangan dengan syari"at Islam. Prisnip-prinsip itu ditempatkan sebagai syarat sahnya akad dan termasuk syarat yang diakui, bukan syarat yang bertentangan dengan akad (mulghah). Justru keberadaannya memperkuat keberadaan tujuan akad asuransi yang telah terbentuk.
\end{abstract}

Kata kunci: Asuransi, Maqashid, Perundangan

\section{PENDAHULUAN}

Membahas yang berhubungan dengan Hukum Islam, maka kita akan juga mendengar dengan hukum taklifi berdasarkan jumhur ulama, yakni berupa hukum yang mengatur tentang Wajib, Haram, Sunah, makruh dan mubah. ${ }^{1}$ Berbicara tentang maqashid, maka pokok bahasannya adalah tujuan syariat Islam itu sendiri. Ini dimaksudkan mengenai sebuah pertanyaan "mengapa" sehingga suatu pensyariatan itu diadakan. Dengan kata lain timbulnya pertanyaan bahwa mengapa ada hal tersbut? Pertanyaan-pertanyaan semacam itu merupakan upaya menuju kepada tingkatan filsuf. Pertanyaan-pertanyaan yang timbul semacam ini akan membuat kita semakin mencari tahu akan kebenaran dan keabsahan hal tersebut. Khususnya dalam kajian Hukum Islam perlu dikemukakan metodologi yang tepat sehingga segala kebutuhan Hukum Islam kontemporer mampu terjawab secara baik serta tetap pada tujuan syariat tersebut.

Banyak kajian-kajian yang membutuhkan penelaahan khusus dalam kajian maqashid syariah, sehingga disamping sebagai sumber ilmu juga menjadi sumber kajian yang semakin menarik untuk ditelaah. Misalnya ketika ada orang yang ingin dan berusaha untuk

\footnotetext{
${ }^{1}$ Amir Syarifudin. 2011. Ushul Figh. (Jakarta: Kencana), 338
} 
menjaminkan diri melalui berbagai cara yakni berupa asuransi. Nama ini sangat tidak asing kita kenal dalam industri keuangan nasional dan juga payung hukumnya juga telah diatur secara jelas.

Namun masalah asuransi yang akhir-akhir ini banyak terjadi tentang asuransi yang justru gagal membayar klaim peserta asuransi dikarenakan sesuatu hal. Sehingga perusahaan mengalami kerugian dan nasabah juga tidak mendapatkan kembali polis asuransi tersebut. Misalnya kasus yang cukup terbaru hari ini yakni perusahaan milik negara yang mengalami kerugian sehingga gagal untuk membayar klaim asuransi yang diminta oleh nasabah. Disamping perusahan milik negara ada juga perusahaan swasta dalam kondisi sama yang tidak mampu membayar atas klaim nasabah. ${ }^{2}$ Hal tersebut tergolong masalah yang cukup rumit asuransi konvensional yang terjadi di Indonesia.

Dilihat pada sisi kontrak yang dilakukan pada perusahaan asuransi konvensional mengalami berbagai masalah. Masalah tersebut timbul dikarenakan 1) ketidakpastian dalam hal sumber dana yang dipakai untuk klaim 2) adanya spekulasi sehingga dimungkinkan ada yang diuntungkan dan ada yang dirugikan dan 3) mengandung unsur pembungaan yang sering terjadi dikarenakan terdapat pada perjanjuan antara perusahaan dengan tertanggung. ${ }^{3}$ Dalam hal ini masyarkat semakin mulai mengerti sehingga mencari produk atau lembaga lain yang lebih terjamin, salah satunya dengan beralih pada keuangan syariah.

Dalam Islamic Financial atau keuangan Islam juga melakukan kegiatan Asuransi yang tentunya jauh dan berbeda konsep yang dijalankan sebagaimana pada asuransi konvensional. Amanat Dewan Syariah nasional (DSN) telah mengeluarkan fatwa dengan nomor Nomor 21/DSN-MUI/X/2001, yaitu Asuransi Syariah. ${ }^{4}$ Sehingga ini bisa menjadi landasan awal bagi industri keuangan syariah di Indonesia untuk menjalankan kegaiatan dengan produk asuransi yang berbasis syariah.

Dapat kita temukan berbagai nama-nama dari produk asuransi syariah yang dijalankan oleh perbankan syariah di Indonesia khususnya, misalnya produk AlliSya Care dari asuransi Allianz Syariah. Meskipun demikian, sudah semestinya kita memahami secara mendasar tentang mengapa hal tersebut boleh dijalankan? Pertanyaan tersebut tentu memerlukan jawaban yang kompresensif serta memerlukan metodologi khusus untuk sampai pada tujuan syariat tersebut.

Disinilah metodologi itu berperan untuk mampu menjawab hal tersebut, sehingga sebagai akademisi dan masyarakat mengerti dalam syariat islam terhadap produk yang berkembang di perbankan serta menjadi literasi khusus dalam memahami Asuransi dalam persepektif maqashid syariah dan harmonasasinya dalam perundangan di Indonesia.

\section{METODOLOGI}

Membahas masalah terkait dengan asuransi dari sisi maqashid dan perundangan di Indonesia tentu harus mampu memetakan metodologi yang dikembangkan. Sehingga gambaran tersebut dapat tercapai dengan apa yang seharusnya dijalankan dalam sebuah

2 Anon. n.d. "Undang-Undang Nomor 40 Tahun 2014 Tentang Perasuransian." Retrieved October 12, 2020d (https://www.ojk.go.id/id/kanal/iknb/regulasi/asuransi/undang-undang/Pages/UndangUndang-Nomor-40-Tahun-2014-Tentang-Perasuransian.aspx).

${ }^{3}$ Rizki Redhika dan Kasyful Mahalli. n.d. "Analisis Potensi Dan Kendala Pengembangan Asuransi Syariah Di Kota Medan.” Jurnal Ekonomi Dan Keuangan 2(5)

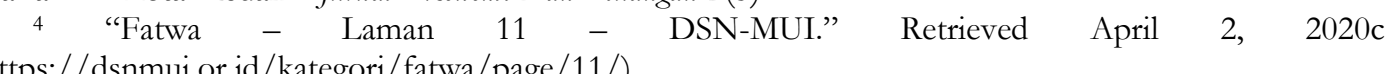
(https://dsnmui.or.id/kategori/fatwa/page/11/). 
penelitian. Sebagaimana dijelaskan bahwa metodologi penelitian sebagai salah satu alat dalam mendapatkan pengetahuan terkait dengan segala aspek yang diyakini kebenaran dalam kajian akademis melalui proses yang sistematis. ${ }^{5}$

Penelitian ini dilihat dari aspek penelitiannya menggunakan pendekatan kualitatif. ${ }^{6}$ Tujuannya adalah untuk memberikan gambaran mendeskripsikan dengan luagas dan kritis sehingga mendapatkan hasil yang sebenarnya. ${ }^{7}$ Akhir dari tulisan ini sebagai upaya untuk menganalis secara Induktif yang berprinsip dari hal-hal khusus guna mendapatkan kesimpulan umum. ${ }^{8}$ sehingga arah dalam pembahasan penelitian ini secara literatur akademik dapat menjadi bahasan menarik untuk dikaji.

\section{TEMUAN}

\section{Telaah Umum Asuransi Syariah}

Memahami asuransi syariah tentunya harus dibarengi dengan dasar umum dari asuransi tersebut. Maksudnya berupa pemahaman terhadap defenisi dari asuransi menjadi poin penting dalam pembahasan penelitian ini. Tujuannya adalah agar penelitian ini lebih terarah dari pembahasan.

Istilah asuransi yang diambil dari kata Insurance yang merupakan kata dari bahasa inggris, oleh tata bahasa indonesia mengadopsi menjadi istilah "asuransi" Bahwa Asuransi dimaknai dengan pertanggungan.' Makna ini juga diterjemahkan oleh Muhammad Muslehuddin dengan pengertian terkait perlengkapan berupa dana yang tersedia dari anggota kelompok kepada yang tertimpa kerugian berupa bencana yang tidak jelas bila diramalkan, sehingga apabila menimpa salah satu anggota kelompok maka anggota yang lain pada kelompok tersebut ikut menanggung beban tersebut. ${ }^{10}$ Makna yang dikemukakan diatas lebih kepada saling tolong menolong antar sesama kelompok, sehingga inilah sikap ta'awn yang perlu dikembangkan oleh orang dalam besosialisasi.

Pengembangan beberapa makna diatas juga meliputi pengertian lain yang dapat ditelusuri. Hal ini dikarenakan berbagai persepsi yang digunakan dan dikembangkan sehingga memunculkan ide-ide baru untuk memahami permasalahan asuransi. Asuransi merupakan suatu pertanggungan yang ditetapkan pada akibat dari perjanjian antara kedua belah pihak yang melakukan kesepakatan yakni si pembayar iuran dan si pemberi jaminan, apabila dikemudian hari terjadi sesuatu misal berupa bencana kepada si pembayar. ${ }^{11}$

Lebih lanjut lagi dijelaskan bahwa asuransi dimaknai sebuah perjanjian dengan konsep pertanggungan pertanggungan dengan ketentuan si penanggung akan membuat ikatan kepada yang tertanggung dengan imbalan hasil akan mendapatkan premi dalam rangka mengganti kerugian yang diterimanya, baik berupa bencana berupa kerusakan atau kehilangan keuntungan akibat dari bencana yang diterimanya. ${ }^{12}$

\footnotetext{
5 W Gulo. 2002. Metodologi Penelitian. (Jakarta: Gramedia Widiasarana Indonesia), 10

${ }^{6}$ Muhammad Ilham. 2020. "Nikah Beda Agama Dalam Kajian Hukum Islam Dan Tatanan Hukum Nasional." TAQNIN: Jurnal Syariah Dan Hukum 2(1), 45

7 A. Muri Yusuf. 2015. Metode Penelitian: Kuantitatif, Kualitatif, dan Penelitian Gabungan. (Jakarta: Kencana), 338

${ }^{8}$ Muhammad Ilham, op.cit, 45

${ }_{9}^{9}$ Departemen Pendidikan Nasional. 2008. Tesaurus Bahasa Indonesia Pusat Bahasa. (Jakarta: Depatemen Pendidikan Nasional), 494

10 Tuti Rastuti. 2016. Aspek Hukum Perjanjian Asuransi. (Yogyakarta: Medpress Digital), 1-2

11 Afif Effendi. 2016. "Asuransi Syariah Di Indonesia (Studi Tentang Peluang Ke Depan Industri Asuransi Syariah).” Wahana Akademika: Jurnal Studi Islam Dan Sosial 3(2), 78

12 Khotibul Umam. 2011. Memahami dan memilih produk asuransi. (Edited by B. Seda. Yogyakarta: Pustaka Yustisia), 5.
} 
Dalam kajian ekonomi bahwa asuransi dimaknai sebagai bentuk penyesuaian komposisi dalam hal ekonomi berupa sesuatu kerugian yang terjadi dimasa depan guna mengantisipasi kemungkinan negatif masa akan datang pada setiap individu. ${ }^{13}$

Dalam buku Dictionary of Islam ditulis oleh Thomas Patrick yang dikutip oleh Abdullah amrin dijelaskan tentang ada suatu pembunuhan yang dilakukan oleh kelompok lain, maka ada bentuk pemberian yang dilakukan kepada pewaris dalam bentuk uang atau istilahnya dikenal dengan uang darah atau dikenal berupa Diyat sebagai kompensasi dari keluarga sipembunuh. ${ }^{14}$

Berdasarkan paparan diatas jelaslah dikemukakan bahwa asuransi pada dasarnya berbentuk pertanggungan, namun yang harus dipahami terlebih dahulu adalah terkait dengan sisi pertanggungan tersebut yakni berupa perusahaan sebagai penguasa dana atau perusahaan sebagai penghubung dalam membantuk sesama rekan anggota.

Ulasan tersebut diatas, maka perlu diketahui setidaknya ada 4 unsur yang terkandung dalam makna yang telah jelaskan sebelumnya, yakni:

a. Pihak tertanggung (Insured). Dalam hal kegiatannya akan memberikan dalam bentuk sejumla uang premi kepada penanggung dilakukan secara sekaligus atau berupa angsuran.

b.Pihak penanggung (Insurer). Fokus kegiatannya berupa memberikan dalam bentuk sejumlah uang kepada anggota (tertanggung) yang dilakukan secara sekaligus atau secara berangsur-angsur dengan ketentuan apabila terjadi pristiwa yang tidak tentu dari anggota. c. Peristiwa (Accident). Kondisi dimana hal yang tidak diinginkan itu terjadi dan tidak terduga d.Kepentingan (Interest). Suatu keadaan yang mengalami kerugian karena kejadian tertentu. ${ }^{15}$

Setelah melihat berbagai pengertian asuransi secara umum, maka perlunya melihat tentang konsep asuransi syariah yang dikemukan, terlebih lagi dasar ini telah tertuang dalam Fatwa Dewan Syariah Nasional (DSN). Upaya melihat kearah sistem syariah diharapkan mendapatkan konklusi khusus tentang asuransi, sehingga makna dan tujuan asuransi syariah tidak disalahgunakan pada oknum.

Dalam acuan fatwa DSN dikemukakan bahwa makna asuransi adalah dijelaskan sebagai usaha dalam kontek perlindungan oleh anggota kelompok melalui jalur penyertaan modal setiap anggota dengan mekanisme aset dan tabarru' sehingga ketika menghadapi resiko tertentu maka dapat dikembalikan melalui akad yang sesuia ketentuan syariah. Asuransi syariah dikenal sebagai takaful, adalah asuransi berbasis syariah. Tujuannya adalah kesetaraan di antara anggota, karenanya dasar-dasar asuransi syariah saling membantu dan melindungi. Ini mewakili Al-Qur'an dan Hadits Suci. ${ }^{16}$ Perihal asuransi syariah, maka konsep ini berasal dari suku arab yang memiliki sebuttan dengan al-aqilah, hingga pada masa Muhammad SAW konsep itu tetap diterima serta menjadi bagian dari Hukum Islam. ${ }^{17}$

Jika mengacu pada Undang-undang Nomor 40 Tahun 2014 tentang Perasurnsian pada pasal 1 ayat 2 bahwa "Asuransi Syariah adalah kumpulan perjanjian, yang terdiri atas perjanjian antara perusahaan asuransi syariah dan pemegang polis dan perjanjian di antara para pemegang polis, dalam rangka pengelolaan kontribusi berdasarkan prinsip syariah guna saling menolong dan melindungi dengan cara: a. memberikan penggantian kepada peserta atau pemegang polis karena kerugian, kerusakan, biaya yang timbul, kehilangan keuntungan, atau tanggung jawab hukum kepada pihak ketiga yang mungkin diderita peserta atau pemegang polis karena terjadinya suatu peristiwa yang tidak pasti; atau b. memberikan pembayaran yang didasarkan pada meninggalnya peserta atau pembayaran yang didasarkan

\footnotetext{
13 ibid

14 Abdullah Amrin. 2011. Meraih Berkah Melalui Asuransi Syariab: Ditinjau Dari Perbandingan Dengan Asuransi Konvensional. (Elek Media Komputindo), 4

${ }^{15}$ Khotibul Umam, op. cit, 6

16 Kuat Ismanto. 2018. "Understanding on and Need for Syaria Insurance: A Case Study in Pekalongan, Central Java, Indonesia." Journal of Accounting and Investment 19(2),139

17 Abdullah Amrin, op. cit, 3
} 
pada hidupnya peserta dengan manfaat yang besarnya telah ditetapkan dan/atau didasarkan pada hasil pengelolaan dana."

\section{Dasar Penetapan Asuransi}

Ketentuan sumber Hukum Islam menjadi pedoman dalam menentukan suatu kegiatan termasuk dalam hal kegiatan muamalah, sumber itu meliputi Al-Quran dan Sunnah. Pada kedua Pedoman tersebut dapat dikatakan sumber Hukum Islam dikarenakan padanya terdapat petunjuk utama kepada hukum Allah. ${ }^{18}$

Dalam prihal asuransi, beberapa dasar rujukan tentang dalil yang menunjukkan kebolehan menjalankan dengan mekanisme asuransi. Berikut ini beberapa dasar yang digunakan untuk menggunakan asuransi.

a. Al-Qur'an

Allah SW'T telah telah memberikan arahan melalui Al-Qur'an dengan menunjukkan dalil tentang konsep melaksanakan dengan asuransi, dalam hal ini terdapat pada surah alMaidah : 2 Allah Berfirman ${ }^{19}$

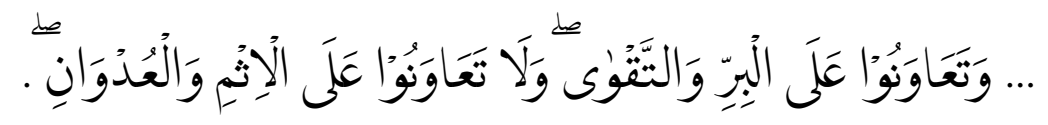

Artinya: Dan tolong-menolonglah kamu dalam (mengerjakan) kebajikan dan takwa, dan jangan tolongmenolong dalam berbuat dosa dan permusuban...

b.Hadits

Kemudian hal yang sama juga dijelaskan pada Hadits Nabi yang berkaitan dengan penjelasan sikap tolong menolong, terdapat dalam Hadits Nabi yang diriwayatkan oleh Muslim dalam kitab nomor 4677 dalam Ensiklopedi Hadits:

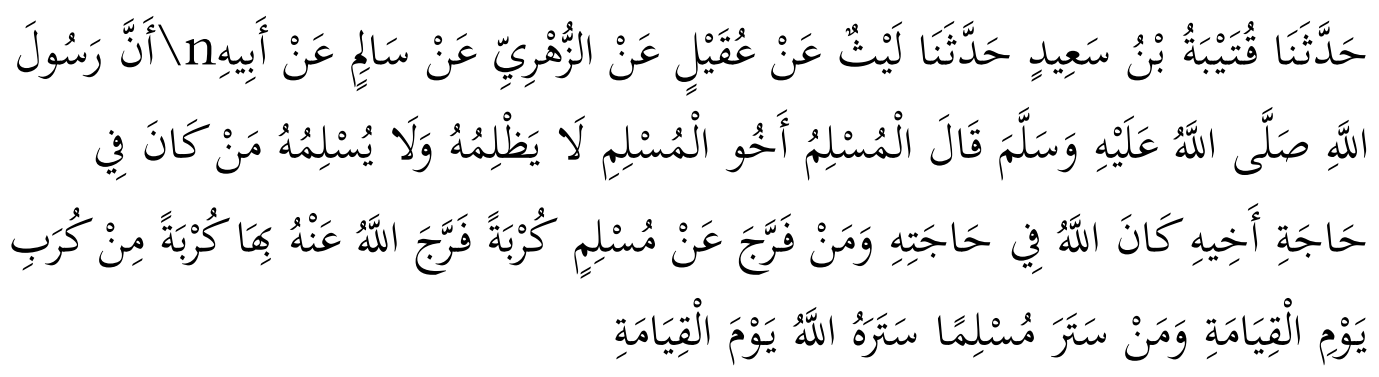

Artinya: Telah menceritakan kepada kami Qutaibah bin Sa'id; Telah menceritakan kepada kami Laits dari 'Uqail dari Az Zubri dari Salim dari Bapaknya bahwa Rasulullab bersabda, "Seorang muslim dengan muslim yang lain adalab bersaudara. Ia tidak. boleh berbuat zalim dan aniaya kepada saudaranya yang muslim. Barangsiapa yang membantu kebutuban saudaranya, maka Allab akan memenubi kebutuhannya. Barangsiapa membebaskan seorang muslim dari suatu kesulitan, maka Allah akan membebaskannya dari kesulitan pada hari kiamat. Dan barangsiapa menutupi aib seorang muslim, maka Allah akan menutupi aibnya pada bari kiamat kelak. (HR. Muslim No. 4677)

Hal ini mengacu pada undang-undang perasuransian yang berlaku. Maka dalam hal ini aturan secara umum yang mengatur dalam perasuransian terdapat dalam Undangundang Nomor 40 Tahun 2014 tentang Perasuransian. Pada undang-undang ini terdiri dari 92 Pasal yang berlaku tentang perasuransian. Meskipun demikian pada Undang-undang ini menyatukan prinsip asuransi kedalam satu Undang-undang yakni asuransi umum dan Asuransi syariah.

\footnotetext{
${ }^{18}$ Satria Effendi. 2005. Ushul Fiqh. edited by H. M. N. Irvan, A. Latif, and H. A. Ya'qub. (Jakarta: Kencana), 73

${ }^{19}$ Departemen Agama RI. 2002. Mushaf Al-Quran Terjemah. (Jakarta: Pena Pundi Aksara), 107
} 
Hal utama dalam kagiatan asuransi berupa telong menolong, sehingga seharusnya yang dicapai dalam prinsip asuransi berupa sikap. Sikap demikian telah tercermin dalam alQur'an dan Sunnah. Penggunaan istilah dasar asuransi demikian dimaksudkan untuk menemukan titik utama asuransi yang diinginkan.

\section{Perbedaan Asuransi Konvensional dan Asuransi Syariah}

Dalam menjalankan produk asuransi khususnya di Indonesia saat ini yang telah memiliki beragam produk dan jenis asuransi yang ditawarkan. Misalnya mulai dari jenis asuransi yang memegang prinsip syariah dan juga ada asuransi yang berfokus dalam bentuk umum atau konvensional. Kedua jenis prinsip yang ditawarkan memiliki karakteristik berbeda pula dalam proses menjalankannya.

Berikut penulis paparkan tentang perbedaan konsep Asuransi syariah dengan konsep asuransi konvensional mengacu dibeberapa literatur yang dikemukakan antara lain mengambil konsep dari Kuat Ismanto ${ }^{20}$ dan juga mengelaborasi juga pada konsep yang ditulis oleh Jaenal Efendi. ${ }^{21}$ Perbedaan tersebut tergambar dalam tabel dibawah ini.

\section{Tabel 1. Perbedaan Konsep Asuransi Syariah dengan Asuransi Konvensional}

\begin{tabular}{|c|c|c|}
\hline Aspek & Asuansi Syariah & Asuransi Konvensional \\
\hline $\begin{array}{l}\text { Dasar } \\
\text { Hukum }\end{array}$ & Al-Qur'an dan Sunnah & $\begin{array}{l}\text { Hukum Positif dan Atas } \\
\text { gagasan manusia }\end{array}$ \\
\hline Kontrak & $\begin{array}{l}\text { Saling membantu } \\
\text { (Ta'awun) }\end{array}$ & Berdasarkan persetujuan \\
\hline $\begin{array}{l}\text { Aktivitas } \\
\text { Investasi }\end{array}$ & $\begin{array}{c}\text { Bebas riba dan } \\
\text { Aktivitas yang tidak sesuai } \\
\text { ketentuan syariah }\end{array}$ & $\begin{array}{l}\text { Tidak bebas riba dan } \\
\text { Aktivitas yang tidak sesuai } \\
\text { ketentuan syariah }\end{array}$ \\
\hline $\begin{array}{l}\text { Kepemilik } \\
\text { an Dana }\end{array}$ & $\begin{array}{c}\text { Anggota memiliki hak } \\
\text { dana sementara perusahaan } \\
\text { asuransi hanya mengelola } \\
\text { dana }\end{array}$ & $\begin{array}{l}\text { Perusahaan asuransi } \\
\text { memiliki hak dana }\end{array}$ \\
\hline $\begin{array}{l}\text { Sumber } \\
\text { Klaim Dana }\end{array}$ & Dana Tabarru’ & $\begin{array}{l}\text { Dari akun dana perusahaan } \\
\text { asuransi }\end{array}$ \\
\hline $\begin{array}{l}\text { Keuntung } \\
\text { an }\end{array}$ & $\begin{array}{l}\text { Pembagian keuntungan } \\
\text { dari perusahaan dengan } \\
\text { peserta asuransi sesuai } \\
\text { ketetapan yang telah dibuat }\end{array}$ & $\begin{array}{l}\text { Semua keuntungan milik } \\
\text { perusahaan asuransi }\end{array}$ \\
\hline Konsep & Pembagian Resiko & Transfer Resiko \\
\hline $\begin{array}{l}\text { Sistem } \\
\text { Keuangan }\end{array}$ & Basis uang tunai & Dasar akrual \\
\hline
\end{tabular}

Pada Skema asuransi syariah tentunya berbeda dengan skema pada asuransi konvensional, sebab pada umumnya asuransi syariah mengedepankan pada prinsip 1) prinsip keadilan, 2) Prinsip transparansi, dan 3) pembagian risiko. Makan prinsip nomor 3 tersebut berupaya untuk memberikan perlindungan dalam bentuk properti atau jiwa bagi anggota yang mengalami posisi yang kurang beruntung. ${ }^{22}$

\footnotetext{
${ }^{20}$ Kuat Ismanto, 2018, op. cit, 140

${ }^{21}$ Jaenal Effendi. 2018. "Islamic Insurance: A Potential Niche Market of Indonesia." Al-Iqtishad: Jurnal Ilmu Ekonomi Syariah 10(1)

${ }^{22}$ Ibid, 209
} 
Pada letak perbedaan tersebut makal dapat diperhatikan bahwa Asuransi syariah megupayakan untuk menempatkan nilai-nilai syariah pada konsep asuransi, lebih tepatnya dasar dari asuransi ada pada asuransi syariah. Upaya ke arah maqashid menjadi urgensi dalam pengelelolaan jasa keuangan melalui asuransi.

\section{KAJIAN DASAR MAQASHID SYARIAH}

Membahas permasalahan asuransi pada kajian maqashid syariah menjadi kajian yang selalu menarik dari persepektif fiqh kontemporer, sebab meskipun persoalan ini telah dikemukakan sebelumnya oleh pemikir klasik akan tetapi untuk mencapai maqashid itu sendiri masih selalu mendapatkan posisi terbaik dalam kajian fiqh. Oleh karena itu perlunya defenisi maqashid syariah agar mengetahui secara jelas dari maqashid itu sendiri.

Makna maqashid syariah terbentuk dari dua kata yakni Maqashid dan Syariah, keduanya perlu dipertegas pemahaman tersebut sehingga mendapatkan defensi akhir dari maqashid syariah. Secara bahasa makna maqashid merupakan jamak dari maqsid yang bermakna tuntutan, kesengajaan ataupun tujuan. ${ }^{23}$ Pengertian lain diterjemahkan dengan tujuan, sasaran, hal yang menjadi minat atau tujuan akhir. Dalam pendekatan ilmu syariat dikemukakan bahwa al-Maqashid dapat ditunjukkan pada makna al-hadaf (tujuan), al-garad (sasarn), al-mathlub (minat terhadap sesuatu), dan juga al-gayah (tujuan akhir) dari fiqh atau hukum Islam. ${ }^{24}$

Kemudian kata selanjutnya adalah kata Syariah. Kata ini memilki makna dasar secara etimologi dimaknai dengan jalan menuju pengairan atau dengan makna lain berupa jalan yang harus diikuti atu juga orang arab sering menyebut dengan tempat lalunya air sungai. ${ }^{25}$ Kedua makna diatas dijelaskan oleh al-Syatibi dengan beragam bentuk kata antara lain maqashid al-syari'ah, juga disebut al-maqashid al-syar'iyyah fi al-syari'ah, dan maqashid min syar'i albukm dengan kandungan makna yang sama berupa tujuan ditetapkan ketentuan hukum tersebut. ${ }^{26}$

Maqashid merupakan cabang kajian ilmu keislaman yang selalu mengarahkan pada persoalan-persoalan yang dianggap sulit akan tetapi hadir pada sebuah kata yang tampaknya dianggap sederhana, kata tersebut mewakili pada aspek hikmah dibalik syariat, aspek tujuan syariat berupa kebolehan atau pelarangan, aspek tujuan ilahian dan konsep akhlak. ${ }^{27}$ Sehingga dengan kehadiran maqashid itu diharapkan para mujtahid mampu mengelaborasi pemikiran hukum islam yang berkembang dewasa ini serta fiqh kontemporer yang dapat terselesaikan permasalahannya, terkhusus pada kasus yang secara detail tidak dijelaskan dalam al-Qur'an dan hadits.

Dengan demikian, kajian maqashid syariah berupaya mengemukakan tujuan dasar dari penetapan hukum tersebut. Tujuan inilah yang harusnya dicapai oleh mujtahid pada setiap penetapan hukum yang berkembang dimasyarakat. Sehingga segala permasalahan hukum islam yang ditetapkan bertujuan untuk meraih kemasalahatan hidup umat manusia. ${ }^{28}$

Al-maqashid terus mengalami banyak perubahan dari segi klasifikasi, sehingga tergantung dari dimensi mana yang dipandang oleh seorang ulama atau fakih. Klasifikasi dalam kajian klasik pada al-maqashid meliputi 3 jenjang: yakni berupa: al Dharuriyyat (keniscayaan), Al-Tahsiniyyat (Kebutuhan) dan al-Hajiyyat(kemewahan). ${ }^{29}$

Pada kajian al-Dharuriyyat (keniscayaan) berupa hal yang harus dipenuhi dalam setiap permasalah hukum atau menjadi sebuah kebutuhan primer. Oleh karena itu, para

\footnotetext{
${ }^{23}$ Intan Cahyani. 2014. "Teori Dan Aplikasi Maqashid Al-Syari'ah.” Jurnal Al-Qadau: Peradilan Dan Hukum Keluarga Islam 1(2), 21

${ }^{24}$ Jaser 'Audah,. 2013. Al-Maqasid Untuk Pemula. (Yogyakarta: Suka Press), 6

25 Amir Syarifudin, op.cit, 1

${ }^{26}$ Intan Cahyani, op. cit, 21

${ }^{27}$ Jaser 'Audah, op. cit, 3-5

${ }^{28}$ Satria Effendi, op. cit, xii

${ }^{29}$ Jaser'Audah, op. cit, 8
} 
ulama membagi kepada 5 kategori dan sebagian ulama menambahkan 1 kategori lagi. Kategori tersebut antara lain: 1) Hifz al-Din (pelestarian agama), 2) Hifz al-Nafs (pelestarian jiwa), 3) Hifz al-Mal (pelestarian harta), 4) Hifz al-'Aql (pelestarian Akal), 5) Hifz al-Nashl (pelestarian keturunan), serta menambahkah juga dengan kategori ke 6) Hifz al-Ird (pelestarian kehormatan). ${ }^{30}$

\section{Gambar 1}

al-Macashid (dari nersenektif keniscavaan)

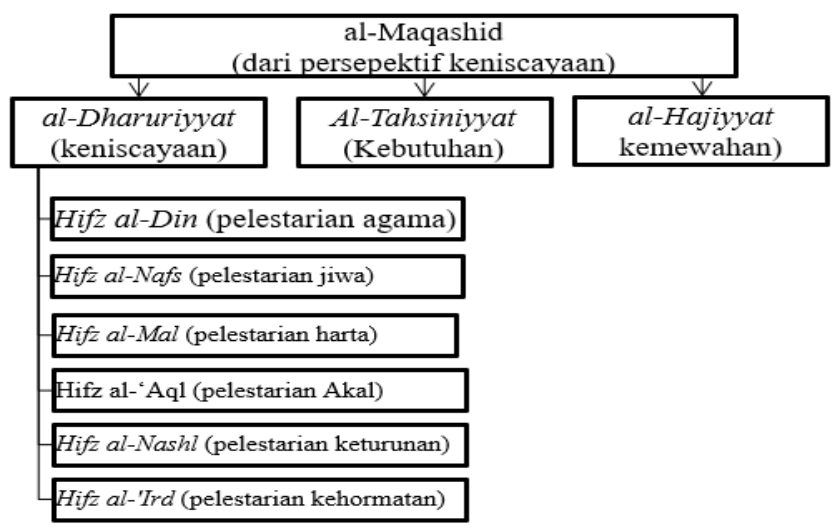

\section{DISKUSI}

\section{Analisis Maqashid Syariah pada Asuransi Syariah}

Pengembangan lembaga keuangan syariah sebagai salah satu upaya menghindari adanya praktek keuangan ribawi yang cukup menyebar diberbagai belahan dunia, melihat dari karakteristik sistem keuangan yang mengarah pada liberalis yang cukup menyulitkan bagi nasabah. Kehadiran sistem keuangan yang berbasis syariah bukan baru ini saja kehadirannya, akan tetapi justru menjadi hal ini menjadi solusi terbaik dalam menjalankan sistem keuangan dilembaga keuangan syariah.

Diketahui juga bahwa sistem syariat islam merupakan cara hidup yang dibenarkan oleh Allah dan juga atas perintah Nya, sehingga aturan ini berlaku untuk seluruh umat manusia. ${ }^{31}$ Dalam konteks muamalah hal ini tentu sangat diperlukan, sebab syariat Islam bukan hanya pada aspek ibadah, akan tetapi juga pada kaidah muamalah. Pada setiap kegiatan muamalah termasuk pada aspek asuransi yang dijalankan tentu harus sesai dengan syariat Islam. Upaya ini dikemukan tentu memberikan keadilan dalam berekonomi serta kemakmuran masyarakat.

Pada dasarnya istilah asuransi yang dikenal dimasyarakat terlihat pada 2 pokok masalah yang akan dikaji, yakni berupa lembaga sosial atau ekonomi dengan tujuan tertentu dan secara hukum termasuk perjanjian antara dua belah pihak. ${ }^{32}$

Setelah melihat perbedaan konsep asuransi syariah dan konvensional pada poin sebelumnya, jika dipehatikan melalui persepekti ilmu fiqh, maka sudah dapat diketahui bahwa konsep pada asuransi konvensional sangat bertentangan dengan nilai-nilai ilmu muamalah. Pembahasan mengenai asuransi dengan analisis maqashid syariah ini berupaya untuk mendapatkan jalan tengah dari tujuan dari hukum atas suatu produk tersebut. Oleh

\footnotetext{
30 ibid

${ }^{31}$ Netta Agusti. 2019. "Relevansi Asuransi Syari'ah Dengan Konsep Maqashid Syari'ah: Telaah Indikator." Saqifah: Jurnal Hukum Ekonomi Syari'ah 4(1), 66

32 Arijulmanan. 2017. "Asuransi Dalam Islam." Al-Mashlahab: Jurnal Hukum Islam Dan Pranata Sosial Islam 1(01), 600
} 
karena itu Pembahasan maqashid syariah dalam produk asuransi yang berkembang dimasyarakat diupayakan memetakan secara umum baik dalam bentuk asuransi syariah maupun bentuk asuransi konvensional khususnya pada tingkat maqashid syariah addharuriyyat.

1.Hifzal-Din (Pelestarian Agama)

Agama merupakan hal yang sangat dibutuhkan oleh setiap manusia, hal ini mengingatkan bahwa agama setiap manusia akan terasa hampa jika tanpa agama. Sehingga adanya agama selalu membimbing kearah yang benar. Agama mengajarkan banyak hal mulai dari prinsip akidah sampai juga kepada prinsip muamalah (hablum minannas).

Syariat Islam pada awalnya menjadi tolak ukur uatama dalam menjaga eksistensi pada semua agama, baik pada masa agama yang masih berlaku, maupun pada agamaagama yang ada sebelumnya. Sebagai upaya akan kebutuhan agama pada setiap individu, oleh karena itu setiap individu manusia tentunya harus mentaati perintah Tuhan dari masing-masing Agama, pada agama Islam khususnya Allah SWT yang memerintahkan manusia untuk mentaati Nya dengan menjalankan segala perintah dan larangan Nya, sehingga pada saat itu pula manusia disebut dengan abdi. Sebagaimaa Allah berfiman dalam al-Quran surah az-Zariyat ayat : 56 sebagai berikut:

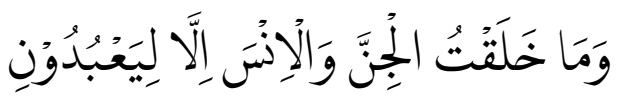

Artinya: Aku tidak menciptakan jin dan manusia melainkan agar mereka beribadah kepada-Ku

Pemaknaan ibadah dalam ayat diatas menurut rozalinda yang dikutip oleh netta agusti berupa hukum-hukum Allah yang berhubungan dengan keseharian manusia dalam mencapai tujuan agama. ${ }^{33}$ Oleh karena itu hubungan timbal balik dari manusia yang membutuhkan Agama dan Allah sebagai pencipta, disamping itu Allah memberikan aturan main dalam kelangsungan keselarasan hidup manusia. Dari hubungan tersebut harus tercapai sehingga tujuan tersebut dapat tercapai.

Mengenai asuransi bahwa pemaknaan asuransi pada dasarnya adalah bentuk tolong menolong antar sesama umat manusia dan bahkan antar agama. hal tersebut masih dapat dibenarkan terkecuali jika sudah masuk pada masalah akidah.

Pada sisi maqashid dalam Hifz al-Din pada produk asuransi yang ditekankan bahwa adanya asurnasi diharapakan sesama anggota saling tolong menolong antara sesama anggota yang mengalami musibah. Prinsip ini selaras dengan adanya konsep agama yang dengan tujuannya merupakan mengatur agar masing-masing saling membantu serta agama juga menghindari perbuatan zalim antar sesama dan juga meletakkan Al-Quran dan Sunnah sebagai dasar hukum pembentukannya.

Jika melihat pada 2 jenis asuransi yang ada saat ini tentunya kita dapat melihat bahwa pada konsep asuransi konvensional yang terlihat dibentuk pada Hukum Positif serta gagasan manusia, hal ini dikhawatirkan memunculkan konflik kepentingan dalam perumusan hukum, sehingga berimbas pada aturan main dalam produk tersebut yang bisa saja ada upaya untuk mementingkan salah satu pihak dan pihak yang lain dirugikan.

Pada Asuransi syariah yang kita kenal prinsip yang dijalankan berupa takaful (jaminan bersama) serta solidaritas. ${ }^{34}$ Sehingga dalam hal ini semakin memberikan perbedaan dengan konsep yang dijalankan pada asuransi konvensional. Hal ini terlihat pada letak perbedaan yang dikemukakan pada tabel bahwa dasar hukumnya adalah alQur'an dan Sunnah.

${ }^{33}$ Netta Agusti, op. cit, 8

34 Ibrahim Warde. 2009. Islamic Finance: Kenangan Islam Dalam Perekonomian Global. (Yogyakarta: Pustaka Pelajar), 315 


\section{Hifz, al-Nafs (Pelestarian Jiwa)}

Unsur berikutnya yang terpenting dalam maqashid adalah melestarikan jiwa. Dalam kaitannya dengan jiwa, maka jiwa sebagai perangkat yang sangat penting. Artinya jika jiwa terancam, maka akan sangat sulit untuk melakukan hal diinginkan. Akan tetapi jika jiwa merasa aman, tenteram dan damai sudah tentu harus mengerjakan perbuatan yang sesuai dengan kaidah-kaidah agama dan kehidupan sosial.

Dalam konsep dharuriyah yang dijalankan, bentuk pelestarian jiwa dimaknai dengan sesuatu yang merasa sangat merugikan jiwa dapat dilakukan dalam hal negatif, seperti mencegah adanya kecelakaan, hal ini bisa dianggap upaya mencegah, melestarikan dan melindungi. ${ }^{35}$

Dalam konsep Asuransi yang berkembang dimasyarakat bahwa sejalan dengan konsep tujuan syariat bahwa untuk mengembangkan nila-nilai perjuangan umat, maka diperlukan jiwa yang dalam keadaan sehat. Namun yang paling penting ketika terjadi hal yang dapat menyebabkan kerugian dalam aspek kesehatan dan pendidikan, maka upaya mempertahankan hal tersebut adalah dengan mengikutsertakan dalam asuransi.

3. Hifz al-Mal (Pelestarian Harta)

Hifz al-mal dimaknai sebagai bentuk pemberian jaminan dalam kepemilikan harta benda, properti dan lain-lain. Sehingga makna ini tersirat tentang terlarangnya mengambil hak orang lain atas hartanya baik dengan jalan pencurian, korupsi dan jinayah lainnya. Pujiono. 2011. Hukum Islam Dan Dinamika Perkembangan Masyarakat. Jember: STAIN Jember Press. ${ }^{36}$ Harta dijadikan sebagai salah satu aspek dalam kajian Maqashid Syariah sehingga harus ada bentuk perlindungan secara syariah. Meskipun disadari bahwa harta adalah kepunyaan Allah, namun manusi berhak atas kepemilikan harta tersebut dan mengelola harta dengan sebaik mungkin. ${ }^{37}$

Kajian Asuransi sebagai bentuk kajian ekonomi yang tentunya masuk dalam aspek muamalah. Oleh karena itu segala bentuk bisnis yang dijalankan dengan tujuan memenuhi kebutuhan hidup. Berbagai bentuk kegiatan muamalah yang dapat ditemukan dibidang ekonomi seperti al-bai, rahn, mudharabah, dan lainnya akan menjadi halal dan sesuai konsep muamalah apabilan dijalankan pada norma-norma bidang muamalah yang bersumber dari sumber agama. Kegiatan seperti ini tentu termasuk dalam hal positif (jabijab), namun ada juga kegiatan yang secara Agama telah melarangnya misalnya ada unsur riba, tagrir, tadlis, maisir, dll.

Dalam pemahaman literasi bahwa asuransi bertujuan untuk menjaga kemaslahatan harta yang dimiliki oleh seseorang. Sehingga yang dapat dijadikan sebagai sebagai objek asuransi adalah harta yang dimiliki oleh seseorang atas kepemilikannya. Bentuk mengedepannya aspek kepentingan harta sebenarnya hal tersebut mengarah pada aspek negatif, seharusnya yang mengarah pada aspek positi sebagai usaha perwujudannya. Asuransi yang seperti ini banyak dijumpai pada asuransi kerugian, yakni dengan makna bahwa asuransi menghadirkan bentuk penanganan resiko atau kerugian, dalam bentuk kehilangan manfaat dan juga bentuk tanggung jawab hukum pihak ketiga atas suatu peristiwa yang tidak diinginkan sebelumnya. ${ }^{38}$

4. Hifz al-'Aql (Pelestarian Akal)

Akal diberikan kepada kita untuk mengetahui mana yang haq dan mana yang bathil. Dengan akal yang diberikan, maka manusia dapat mengembangkan ide-ide agar

\footnotetext{
35 Agus Marimin,. 2019. "MAQASHID KAJIAN ASURANSI SYARIAH.” Jurnal Education and Economics 2(03), 266

36 Pujiono. 2011. Hukum Islam Dan Dinamika Perkembangan Masyarakat. Jember: STAIN Jember Press), 64

${ }^{37}$ Kuat Ismanto. 2016. Asuransi : perspektif maqasid asy-syariah. (Cet. 1. Yogyakarta: Pustaka Pelajar), 147

38 ibid, 148
} 
kehidupan itu menjadi lebih baik. Sebaliknya, apabila akal dikembangkan hanya untuk pemuasan nafsu belaka maka hal tersebut akan menjadi kerusakan, baik dalam individu maupun dalam lingkungan masyarakat.

Adanya larangan Riba, gharar dan Maysir dalam pembahasan pada asuransi menginginkan bahwa perbuatan tersebut menghindari dari sifat-sifat tercela. Sehingga apabila mentaati dan meyakini pelarangan tersebut maka tidak adanya problematika dimasyarakat, sehingga terjadi kerukunan dalam bermasyarakat.

5.Hifz al-Nashl (Pelestarian Keturunan)

Hifz, al-Nashl atau pelestarian keturunan adalah bentuk menjaga keturunan dari hal-hal yang dapat melemahkan serta membuat kepunahan. Makna lain berupa bentuk jaminan atas privisi individu dengan bentuk upaya melindungi atas pekerjaan, melindungi masa depan dengan generasi penerus yang terbaik serta memiliki kualitas, Sehingga islam dalam aturan syara' juga memberikan bentuk pelarangan pada keadaan sex bebas, prilaku homoseksual serta zina. ${ }^{39}$

Membahas tentang masalah keturunan sangat penting untuk dikaji, bukan hanya bgi umat Islam akan tetapi juga bagi para pemikir muslim yang membahas tentang kajian Maqashid Syariah. Pokok kajian ini dalam konsep pernikahan masuk dalam kategori aspek positif (ijabiyah) yakni sebagai upaya untuk melestarikan keturunan melalui pernikahan. Aspek negatif (salbiyah) hal ini berhubungan dengan upaya pelarangan terhadap perbuatan zina dan memberikan ketetepan dengan jalan pernikahan. ${ }^{40}$

Dalam literasi kajian asuransi bahwa hal pokok dalam memberikan perlindungan asuransi adalah para ahli waris. Ahli waris memiliki hak atas harta dari orang tua mereka,hal ini disebabkan bahwa anak memiliki hubungan kekerabatan atau hubungan darah dengan orang tua hingga sampai kepada perwalian sedangkan orang tua memiliki hak untuk hidup serta keberlangsungan kehidupannya. Asuransi yang bisa dijalankan berupa asuransi berupa pendidikan oleh keturunan. Jadi peranan asuransi ini sebagai bentuk kemaslahatan keturunan sebagai bentuk melindungi keuangan oleh keturunan agar tetap terjaga dari bahaya yang menyebabkan kelemahan. ${ }^{41}$

6.Hifz al-Ird (Pelestarian Kehormatan)

Konsep Hifz al-Ird dimaknai dengan upaya menjauhkan diri dari bentuk perbuatan yang dilarang dalam konsep agama. ${ }^{42}$ Sehingga dapat dipahami bahwa hal tersebut bukan hanya menyangkut persoalan duniawi semata, akan tetapi berkaitan dengan aspek Ibadah dalam menjalankan kegiatan muamalah.

Terkait dengan Konsep Hifz al-Ird atau pelestarian kehormatan menjadi penjelas bahwa perlunya perlindungan terhadap harkat dan martabat atas pemeliharaan hak asasi manusia, sehingga ketercapaian ini diharapkan mampu mengaplikasikan dalam kegiatan muamalah. ${ }^{43}$

\section{PENUTUP}

Asuransi adalah persoalan kontemporer yang belum ditemukan hukumnya, baik dalam al-Qur"an maupun as-Sunnah. Oleh karena itu perlu upaya sungguh-sungguh menemukan hukumnya sehingga bisa dijadikan pegangan umat Islam tetang status

\footnotetext{
${ }^{39}$ Pujiono, op.cit, 64

${ }^{40}$ Kuat Ismanto. 2016, op. cit, 145

${ }^{41}$ Ibid, 147

42 Huzaemah Tahido Yanggo, Huzaemah Tahido. 2019. "Hukum Melindungi Keturunan Dan Kehormatan Menurut Islam.” Al-Mizan: Jurnal Hukum Dan Ekonomi Islam 3(1), 19

43 Faizin. 2019. "Rekonstruksi Maqâshid Al-Syarî’ah Sebagai Metodologi Tafsir Kontemporer." Majalah Ilmu Pengetabuan Dan Pemikiran Keagamaan Tajdid 22(2), 179
} 
hukumnya. Upaya itu tidak hanya sekedar ijtihad klinis tentang kehalalan dan keharamannya, tetapi ditinjau dari sudut pandang filsafat hukum Islam, seperti maqasid asysyariah. Implementasi teori maqasid asy-syariah memberi warna baru dalam pembahasan asuransi. Ada titik temu antara tujuan ditetapkannya syariah dengan maksud diadakannya asuransi. Peranan asuransi dalam melindungi al-kulliyah alkhams bisa berupa ijabiyah (perwujudan), bisa juga berupa salbiyah (pencegahan/penolakan). Sehingga secara filosofis bahwa maksud dan tujuan seorang muslim dalam mengikuti program asuransi dengan niatan melindungi agama, jiwa, akal, keturunan, harta dan kehormatan.

Asuransi, meskipun termasuk masalah mu"amalah yang baru, bukanlah praktek yang dilarang, sebab tidak ada dalil nas yang melarang keberadaannya. Disamping itu segala praktek bisnis yang baru tidak dilarang dalam Islam selama tidak betentangan dengan ketentuan syari"ah dan dikelola dalam rangka meningkatkan kesejahteraan umat. Secara esensial dapat dikatakan bahwa adanya prinsip-prinsip hukum asuransi, tidak bertentangan dengan syari"at Islam. Prisnip-prinsip itu ditempatkan sebagai syarat sahnya akad dan termasuk syarat yang diakui, bukan syarat yang bertentangan dengan akad (mulghah). Justru keberadaannya memperkuat keberadaan tujuan akad asuransi yang telah terbentuk. Di sisi lain keberadaannya sebagai alat untuk mengeliminir praktek-praktek bisnis yang dilarang dalam Islam, seperti judi, gharar, penipuan, riba, dan lain sebagainya.

\section{REFERENSI}

Agusti, Netta. 2019. "Relevansi Asuransi Syari'ah Dengan Konsep Maqashid Syari'ah: Telaah Indikator." Saqifah: Jurnal Hukum Ekonomi Syari'ab 4(1):65-74.

Amrin, Abdullah. 2011. Meraih Berkah Melalui Asuransi Syariah: Ditinjau Dari Perbandingan Dengan Asuransi Konvensional. Elek Media Komputindo.

Anon. n.d. "5 Asuransi Kesehatan Syariah Terbaik 2019 (Premi Murah, Produk Bagus)." Retrieved April 2, 2020a (https://duwitmu.com/asuransi/asuransi-kesehatansyariah-terbaik/).

Anon. n.d. "DAI Sebut Ada Perusahaan Asuransi Bermasalah Mirip Jiwasraya." Retrieved April 2, 2020b (https://www.cnnindonesia.com/ekonomi/20200227194935-78478905/dai-sebut-ada-perusahaan-asuransi-bermasalah-mirip-jiwasraya).

Anon. n.d. "Fatwa - Laman 11 - DSN-MUI." Retrieved April 2, 2020c (https://dsnmui.or.id/kategori/fatwa/page/11/).

Anon. n.d. "Undang-Undang Nomor 40 Tahun 2014 Tentang Perasuransian." Retrieved October 12 , $2020 d$ (https://www.ojk.go.id/id/kanal/iknb/regulasi/asuransi/undangundang/Pages/Undang-Undang-Nomor-40-Tahun-2014-TentangPerasuransian.aspx).

Arijulmanan. 2017. “Asuransi Dalam Islam.” Al-Mashlabah: Jurnal Hukum Islam Dan Pranata Sosial Islam 1(01)

'Audah, Jaser. 2013. Al-Maqasid Untuk Pemula. Yogyakarta: Suka Press.

Cahyani, Intan. 2014. “Teori Dan Aplikasi Maqashid Al-Syari'ah.” Jurnal Al-Qadau: Peradilan Dan Hukum Keluarga Islam 1(2).

Djazuli, H. A. 2017. Kaidah-Kaidah Fikih : Kaidah-kaidah Hukum Islam Dalam Menyelesaikan Masalah-masalah yang Praktis. Pertama. Jakarta: Kencana.

Effendi, Afif. 2016. "Asuransi Syariah Di Indonesia (Studi Tentang Peluang Ke Depan Industri Asuransi Syariah)." Wahana Akademika: Jurnal Studi Islam Dan Sosial 3(2) 
Effendi, Jaenal. 2018. "Islamic Insurance: A Potential Niche Market of Indonesia." AlIqtishad: Jurnal Ilmu Ekonomi Syariab 10(1)

Effendi, Satria. 2005. Ushul Fiqh. edited by H. M. N. Irvan, A. Latif, and H. A. Ya'qub. Jakarta: Kencana.

Faizin, Faizin. 2019. "Rekonstruksi Maqâshid Al-Syarîah Sebagai Metodologi Tafsir Kontemporer." Majalah Ilmu Pengetahuan Dan Pemikiran Keagamaan Tajdid 22(2)

Gulo, W. 2002. Metodologi Penelitian. Jakarta: Gramedia Widiasarana Indonesia.

Ilham, Muhammad. 2020. "Nikah Beda Agama Dalam Kajian Hukum Islam Dan Tatanan Hukum Nasional.” TAQNIN: Jurnal Syariah Dan Hukum 2(1).

Ismanto, Kuat. 2016. Asuransi : perspektif maqasid asy-syariah. Cet. 1. Yogyakarta: Pustaka Pelajar.

Ismanto, Kuat. 2018. "Understanding on and Need for Syaria Insurance: A Case Study in Pekalongan, Central Java, Indonesia." Journal of Accounting and Investment 19(2)

Marimin, Agus. 2019. "MAQASHID KAJIAN ASURANSI SYARIAH.” Jurnal Education and Economics 2(03)

Nasional, Departemen Pendidikan. 2008. Tesaurus Bahasa Indonesia Pusat Bahasa. Jakarta: Depatemen Pendidikan Nasional.

Pujiono. 2011. Hukum Islam Dan Dinamika Perkembangan Masyarakat. Jember: STAIN Jember Press.

Rastuti, Tuti. 2016. Aspek Hukum Perjanjian Asuransi. Yogyakarta: Medpress Digital.

Redhika, Rizki, and Kasyful Mahalli. n.d. "Analisis Potensi Dan Kendala Pengembangan Asuransi Syariah Di Kota Medan." Jurnal Ekonomi Dan Keuangan 2(5)

RI, Departemen Agama. 2002. Mushaf Al-Quran Terjemah. Jakarta: Pena Pundi Aksara.

Syarifudin, Amir. 2011. Ushul Fiqh. Jakarta: Kencana.

Umam, Khotibul. 2011. Memahami dan memilih produk asuransi. edited by B. Seda. Yogyakarta: Pustaka Yustisia.

Warde, Ibrahim. 2009. Islamic Finance: Keuangan Islam Dalam Perekonomian Global. Yogyakarta: Pustaka Pelajar.

Yanggo, Huzaemah Tahido. 2019. "Hukum Melindungi Keturunan Dan Kehormatan Menurut Islam." Al-Mizan: Jurnal Hukum Dan Ekonomi Islam 3(1)

Yusuf, A. Muri. 2015. Metode Penelitian : Kuantitatif, Kualitatif, dan Penelitian Gabungan. Jakarta: Kencana. 